\title{
Cement or Calcitonin for Coccyx Fractures
}

\author{
Patrick M. Foye ๑, Harrison R. Massey ๑, Teresa J. Koger ๑
}

Department of Physical Medicine and Rehabilitation, Coccyx Pain Center, Rutgers New Jersey Medical School, New Jersey, United States of America

To the Editor,

We praise your journal and the authors Akar et al. (1) for the wonderful case report titled "Polymethylmethacrylate Cement Augmentation of the Coccyx (Coccygeoplasty) for Fracture: A Case Report." The article and images demonstrate excellent percutaneous placement of cement to effectively treat persistent pain caused by osteoporotic sacrococcygeal fracture.

Before the procedure, their patient had failed to get adequate relief despite trying nonsteroidal anti-inflammatory medications, pillows, and pericoccygeal injection of local anesthetic agents and steroids.

We humbly call the authors' attention to one additional conservative treatment option for coccygeal fracture: intranasal calcitonin. Multiple previous publications have reported the successful use of salmon calcitonin to treat vertebral fracture pain, $(2,3)$ including 1 case series of 8 patients whose vertebral fractures were specifically at the coccyx (4).

We suggest that intranasal calcitonin is a good alternative for those patients with coccygeal fracture who do not have access to clinicians like in Akar's group who have the expertise to provide per- cutaneous cement injections or those patients who are looking for a less invasive treatment option. We would greatly appreciate hearing the authors' thoughts on this treatment option.

Patient Consent for Publication: N/A.

Author Contributions: Concept - P.M.F.; Design - P.M.F.; Supervision - P.M.F., H.R.M., T.J.G.; Resources - P.M.F.; Data Collection and/or Processing - P.M.F.; Analysis and/or Interpretation - P.M.F.; Literature Search - P.M.F., H.R.M., T.J.G.; Writing - P.M.F.; Critical Review - P.M.F., H.R.M., T.J.G.

Conflict of Interest: The authors have no conflicts of interest to declare.

Funding: The authors declared that this study has received no financial support.

\section{REFERENCES}

1. Akar E, Koban O, Öğrenci A, Yılmaz M, Dalbayrak S. Polymethylmetacrylate Cement Augmentation of the Coccyx (Coccygeoplasty) for Fracture: A Case Report. Balkan Med J 2020;37:348-50. [Crossref]

2. Lyritis GP, Tsakalakos N, Magiasis B, Karachalios T, Yiatzides A, Tsekoura M. Analgesic effect of salmon calcitonin in osteoporotic vertebral fractures: A double blind placebo-controlled clinical study. Calcif Tissue Int 1991;49:369-372. [Crossref]

3. Blau LA, Hoehns J. Analgesic efficacy of calcitonin for vertebral fracture pain. Ann Pharmacother 2003;37:564-570. [Crossref]

4. Foye PM, Shupper P, Wendel I. Coccyx fractures treated with intranasal calcitonin. Pain Physician 2014;17:E229-E33.

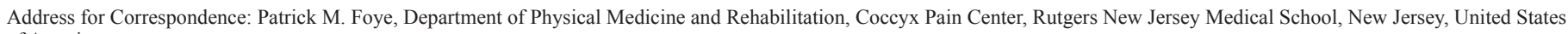
of America

e-mail: Doctor.Foye@gmail.com; Patrick.Foye@rutgers.edu

Received: August 6, 2020 Accepted: August 21, 2020 • DOI: 10.4274/balkanmedj.galenos.2020.2020.8.34

Available at www.balkanmedicaljournal.org

ORCID iDs of the authors: P.M.F. 0000-0002-0889-7700; H.R.M. 0000-0002-8118-1426; T.J.K. 0000-0002-7062-5933.

Cite this article as:

Foye PM, Massey HR, Koger TJ. Cement or Calcitonin for Coccyx Fractures. Balkan Med J 2021;38:63

Copyright@Author(s) - Available online at http://balkanmedicaljournal.org/
} 